\title{
Isolated lateral leg compartment syndrome following an ankle sprain
}

\author{
Joao Teixeira, Carlos Queirós, Nuno Reais, Nuno Tavares
}

Centro Hospitalar de Entre o Douro e Vouga, E.P.E, Santa Maria da Feira, Portugal

\section{Correspondence to} Dr Joao Teixeira, jpedrote@gmail.com

Accepted 13 December 2017

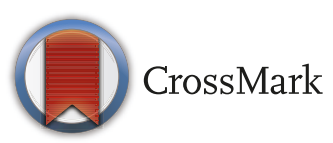

To cite: Teixeira J, Queirós $C$, Reais N, et al. BMJ Case Rep Published Online First: [please include Day Month Year]. doi:10.1136/bcr-2017223517

\section{DESCRIPTION}

A 25-year-old man came to the emergency room after an inversion ankle sprain during a soccer game with friends. He was unable to play after the injury but was able to walk. He complained about a lateral ankle pain that was rapidly increasing in intensity and spreading to the leg. At the first physical examination, we found a lateral malleolus oedema with normal and almost painless dorsi and plantar ankle flexion, but with severe pain with foot inversion and important weakness on foot eversion. He was initially managed with pain medication and leg elevation while waiting for the imagological study.

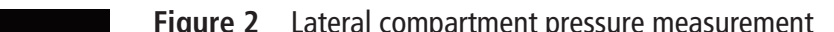
with an invasive blood pressure catheter system connected to the anaesthetic workstation.

The plain X-ray and ankle CT showed no significant bone or soft tissue lesion.

At second evaluation, approximately 1 hour later (4 hours after initial trauma), the patient pain was worst and he had an important oedema and tenderness of the lateral leg compartment (figure 1). $\mathrm{He}$ also started felling some numbness in the dorsum of the foot. The pedal pulses were normal.

Combining all these findings, we suspected of a leg compartment syndrome. The compartment pressure was measured in the operating room with aid of an invasive blood pressure system connected to the anaesthetic workstation (figure 2), because we did not have any specific intracompartmental pressure monitor system available at the emergency room. The lateral compartment pressure was clearly increased measuring $130 \mathrm{~mm} \mathrm{Hg}$ (for a diastolic blood pressure of $80 \mathrm{~mm} \mathrm{Hg}$ ), while the other three compartments had normal pressures.

Being confirmed the lateral compartment syndrome, we performed a lateral compartment fasciotomy and found a partial muscle necrosis with an apparent proximal rupture of the peroneus longus muscle (figure 3). After complete

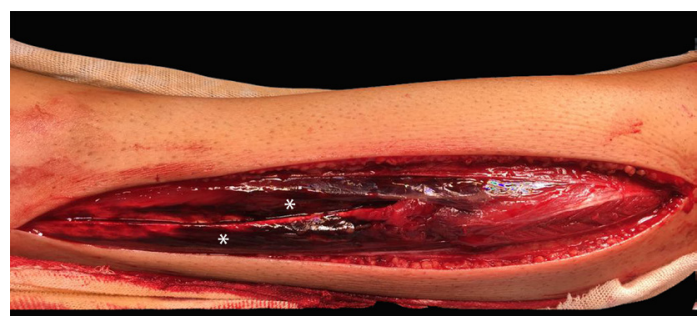

Figure 3 Lateral compartment fasciotomy. Note the blackish tissue representing the necrotic area (asterisk). 


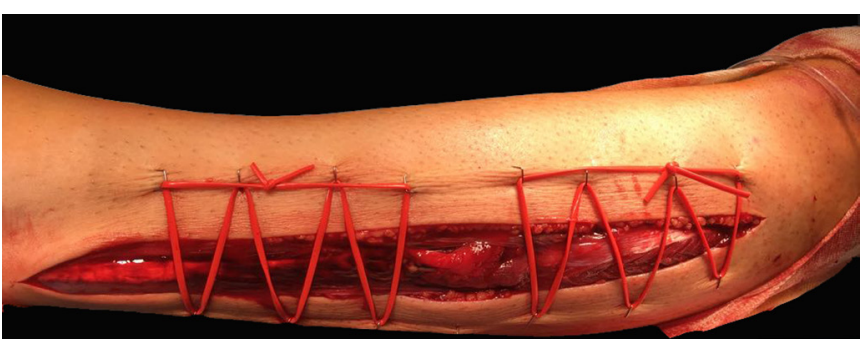

Figure 4 Elastic skin traction using vessel loops through skin staples.
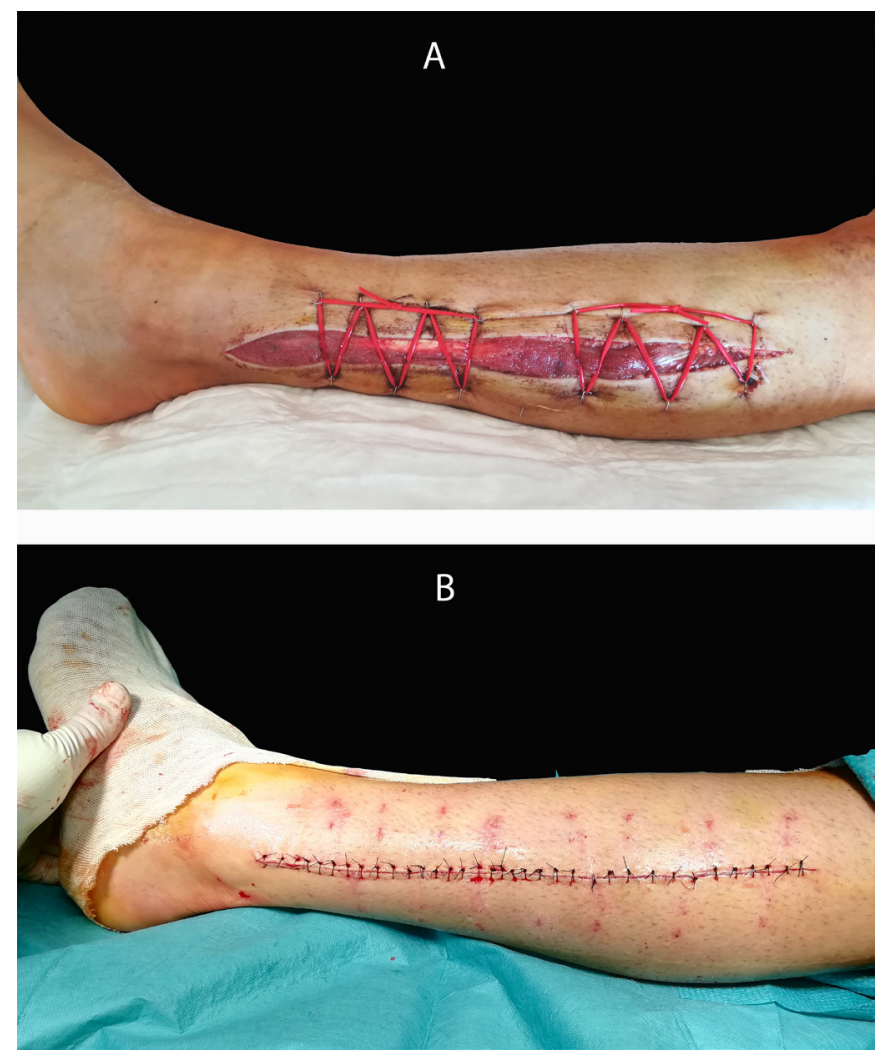

Figure 5 Wound evolution. (A) 48 hours postoperative. Note the complete muscle reperfusion without areas of necrotic tissue. The vessel loops were retensioned at each dressing. (B)Final skin closure at 7 days postoperative.

necrotic muscle debridement and abundant lavage, we did an elastic skin traction using vessel loops through skin staples (figure 4).
The patient reported no pain immediately after the surgical procedure, with complete resolution of sensitive foot impairment at the end of the second day postoperative. The surgical site dressing was performed every 48 hours with progressive elastic skin traction that allowed complete skin closure, without tension, at 7 days postoperative (figure 5). The wound healed without major problems, with the patient being allowed to progressive weight bearing at 2 weeks postoperative. At 6 months follow-up, the patient returned to his sports activities without any limitations.

Isolated lateral compartment syndromes are rare and the ones associated with a non-contact trauma, like ankle sprains, are even rarer. ${ }^{12}$ The peroneus longus rupture is usually found in these cases and the resultant haematoma is thought to be the cause for the pressure elevation. ${ }^{3}$

As every compartment syndrome, the key for a good outcome is an early diagnosis and treatment, since the consequences of the compartment ischaemia can be disastrous. ${ }^{1-3}$

Even the apparent simplest trauma events can hide important complex lesions, so it is important to always perform a careful patient anamnesis and physical examination and be aware of this important syndrome that requires emergent treatment.

\section{Learning points}

Even an apparent simple ankle sprain can be associated with complex problems like a lateral compartment syndrome.

- Acute diagnosis and treatment are crucial for a good outcome in every compartment syndrome.

Contributors JT is the junior surgeon (last year resident) who diagnosed the compartment syndrome, operated the patient and also wrote the paper. CQ and NR are residents who helped in the literature research. NT is the senior surgeon responsible for the surgical procedure and article review.

Competing interests None declared.

Patient consent Obtained.

Provenance and peer review Not commissioned; externally peer reviewed.

(c) BMJ Publishing Group Ltd (unless otherwise stated in the text of the article) 2018. All rights reserved. No commercial use is permitted unless otherwise expressly granted.

\section{REFERENCES}

1 Cheng LY, Niedfeldt MW, Lachacz J, et al. Acute, isolated lateral compartment syndrome after ankle inversion injury. Clin J Sport Med 2007;17:151-2.

2 Rehman S, Joglekar SB. Acute isolated lateral compartment syndrome of the leg after a noncontact sports injury. Orthopedics 2009;32:523-6.

3 Davies JA. Peroneal compartment syndrome secondary to rupture of the peroneus longus. A case report. J Bone Joint Surg Am 1979;61:783-4.

Copyright 2017 BMJ Publishing Group. All rights reserved. For permission to reuse any of this content visit

http://group.bmj.com/group/rights-licensing/permissions.

BMJ Case Report Fellows may re-use this article for personal use and teaching without any further permission.

Become a Fellow of BMJ Case Reports today and you can:

- Submit as many cases as you like

- Enjoy fast sympathetic peer review and rapid publication of accepted articles

- Access all the published articles

Re-use any of the published material for personal use and teaching without further permission

For information on Institutional Fellowships contact consortiasales@bmjgroup.com

Visit casereports.bmj.com for more articles like this and to become a Fellow 